Vol. 13 | No. 2 |159 - 171| August | 2021

ISSN: 2085-3653| e-ISSN: 2549-3116

https://jurnal.unimed.ac.id/2012/index.php/jpk

https://jurnal.unimed.ac.id

\title{
Paper making and characterization from waste coconut and tofu dregs
}

\author{
Erdiana Gultom 1,*, Hestina', Nova Florentina² and Barita Aritonang ${ }^{1}$ \\ ${ }^{1}$ Department of Chemistry, Faculty of Science, Technology and Information, Sari Mutiara University \\ of Indonesia, Medan 20124, Indonesia \\ ${ }^{2}$ Department of Health Analyst, Faculty of Pharmacy and Health Sciences, Sari Mutiara University of \\ Indonesia, Medan 20124, Indonesia \\ *Corresponding author: EG, dyangul25@gmail.com
}

DOI: $10.24114 /$ jpkim.v13i2.27028

Article history:

Received: 17 July 2021

Revised: 25 July 2021

Accepted: 25 July 2021

\begin{abstract}
Research on paper made from coconut and tofu waste has been carried out using the alkalization method of separation technique, with the optimum composition as follows: $\mathrm{NaOH}$ concentration used is $3.0 \%$ and cooking temperature is $100{ }^{\circ} \mathrm{C}$ and the time required is 90 minutes. The results of the catheterization test of paper made from coconut dregs and tofu have a water content of $3.2 \%$; $\mathrm{pH} 6.9$, pulp content $65.75 \%$; cellulose content $80.22 \%$; lignin content $18.27 \%$. The results of the FT-IR spectrum analysis of coconut pulp and tofu pulp are suitable for use as raw materials for making paper because they contain cellulose fibers. This is indicated by the appearance of the $\mathrm{O}-\mathrm{H}$ hydroxyl group which is observed at a wavenumber of $3312 \mathrm{~cm}-1$. Based on the SEM results, the surface morphology of the coconut pulp and tofu combination paper shows that the surface structure is the denser the fiber bonds, the smaller the fiber diameter, the better the mechanical properties. The results of the research conclusions explain that, paper made from coconut and tofu waste has met the requirements set by SNI 14-0444-1989.
\end{abstract}

Keywords: Paper, Cellulose, Coconut pulp, Tofu pulp, Lignin

\section{Introduction}

Paper is one of the basic needs that are very important for society. This can be proven in daily activities, paper is widely used for writing, painting, packaging, photo frames, invitations, letter envelopes (Barbash \& Yashchenko, 2020). So far, the main raw material for making paper uses wood trees from forests, because they contain $40 \%$ cellulose fiber (Abd El-Sayed et al. 2020).

The increasing demand for wood as raw material for papermaking has resulted in frequent illegal logging of timber in the forest through illegal logging practices. Illegal felling of trees through illegal logging practices causes forests to become bare, resulting in 
landslides, floods, water, and air pollution, and global warming. To overcome these problems, renewable raw materials are needed that can replace the role of wood in papermaking, are economical, and do not cause damage to environmental ecosystems, so as to minimize illegal logging in forests and reduce the effects of global warming ( $\mathrm{Li}$ et al. 2008).

Coconut pulp is household waste obtained from the manufacture of coconut milk, while tofu waste is waste obtained from the tofu processing industry. These two wastes are often thrown away, not optimally optimized unless they are only used as animal feed which has low economic value. Even though these two wastes are very potential to be used as raw materials for making paper, replacing the role of wood because they contain high enough cellulose fibers. Coconut pulp has a cellulose content of $16 \%$ while tofu pulp has a cellulose content of 42\% (Mauro et al. 2019; Widayat et al. 2019).

Previous research on paper making with a variety of raw materials and methods has been carried out by Aprianti et al. (2019) reported the process of making paper from bagasse and banana stems using the acetosolve method. The results of the study explained that the paper formed had met the requirements of SNI ISO 287:2010, namely the obtained water content of $3 \%$.

Khan et al. (2014) conducted a study on the manufacture of paper from banana stems with the soda process. The results showed that the paper from banana stems with an optimum cooking time of 120 minutes and a concentration of $2 \% \mathrm{NaOH}$, already met the standards of SNI 14-0444-1989, the pulp content was $61.43 \%$, cellulose content was $83.3 \%$, and lignin content was $2.97 \%$. To produce a good paper that is not easily torn and not opaque (does not change color during use), starch is added to the paper which functions as a binder. The function of adding starch (binder) is to bind the cellulose content contained in coconut and tofu waste so that it is free from lignin so that the quality of the paper produced has better mechanical properties. In this study, the starch used as a binder was cassava peel waste. The process carried out to separate cellulose from lignin contained in coconut waste and tofu waste is by delignification through the alkalization separation method.

Based on the description above, an idea emerged to utilize coconut pulp and tofu waste as renewable raw materials that can replace the role of wood in papermaking. This study aims to determine the optimum composition of papermaking from coconut pulp and tofu waste by studying the hydrolysis time, the effect of cooking temperature, and solution concentration on the characteristics of the paper produced by the alkalization separation method. The results of this study are expected that paper made from coconut pulp and tofu waste has better paper quality than other conventional paper.

\section{Methods}

2.1 Materials and tools

The materials used are coconut pulp, tofu pulp, cassava peel, $\mathrm{NaOH} 1.0 ; 2.0$ and 3.0\%, ethanol $96 \%, \mathrm{H}_{2} \mathrm{SO}_{4} 30 \%$, Sodium hypochlorite. The tools used are autoclave, filter, beaker, measuring flask, Erlenmeyer, funnel, water bath, hotplate, oven, analytical balance, magnetic stirrer, blender, pan, filter paper, baking sheet, furnace, pH meter, SEM, XRD, FTIR, Grammage Test. 


\subsection{Sample preparation}

Samples of coconut dregs and tofu were first washed and dried in the sun, after drying and then blended until they became a fine powder, then put in to remove the moisture content at a temperature of $110^{\circ} \mathrm{C}$ for 60 minutes.

\subsection{Paper making (pulp)}

A total of $100 \mathrm{~g}$ of coconut dregs and tofu powder were weighed and put into an autoclave then $\mathrm{NaOH}$ solution was added with a concentration variation of $1.0 ; 2.0$ and 3\% $(3: 1 \mathrm{w} / \mathrm{v})$, then cooked at temperatures of 80,100 , and $120{ }^{\circ} \mathrm{C}$ for 60,90 , and 120 minutes, while slowly adding $1.0 \mathrm{~g}$ of cassava starch into it and then cooked back. The cooked samples were removed from the autoclave and then cooled to room temperature. The resulting pulp is filtered to separate the residue and the filtrate. The residue obtained was then washed with hot water and $96 \%$ ethanol and then carried out a bleaching process with the addition of sodium hypochlorite, then put in a container and printed according to the desired paper size (Bialkowski et al. 2018). The formed paper was tested for moisture content, pH, cellulose, lignin, and pulp-based on SNI ISO 287:2010, cellulose content, FT-IR, XRD and SEM.

\section{Results and Discussion}

In this study the process of paper made from coconut and tofu waste, obtained the optimum composition as follows cooking time at a temperature of $100{ }^{\circ} \mathrm{C}$ within 90 minutes, the concentration of $\mathrm{NaOH}$ used is $3 \%$. Based on the results of the study obtained water content, $\mathrm{pH}$, pulp content, cellulose content and lignin content.

\subsection{Effect of $\mathrm{NaOH}$ concentration on water content and $\mathrm{pH}$}

High water content and $\mathrm{pH}$ are not good for paper, because they can affect the mechanical properties of the paper produced. In order to produce paper that does not fade, does not tear, and does not have a rough surface, it must have a low moisture content and a normal $\mathrm{pH}$. The water content determined by SNI ISO 287:2010 is less than $5 \%$. The $\mathrm{pH}$ level determined by SNI ISO 6588-1:2010 is 6.9. To find out water content and pH of the paper made from coconut dregs and tofu dregs (Fig 1 and Fig 2). Based on Figure 1, it can be seen that the maximum water content was obtained at a $1.0 \% \mathrm{NaOH}$ concentration of $6.12 \%$, then at a $2.0 \% \mathrm{NaOH}$ concentration, the water content decreased to $4.24 \%$. At $3.0 \% \mathrm{NaOH}$ concentration obtained a minimum water content of 3.06\%. In Fig 2, the maximum $\mathrm{pH}$ level was obtained at a $1.0 \% \mathrm{NaOH}$ concentration of 8.2 then at a $2.0 \% \mathrm{NaOH}$ concentration, the $\mathrm{pH}$ decreased to 7.7. At 3.0\% $\mathrm{NaOH}$ concentration obtained a minimum $\mathrm{pH}$ level of 6.9.

Water content and $\mathrm{pH}$ decreased frequently with increasing $\mathrm{NaOH}$ concentration. This shows that the concentration of the $\mathrm{NaOH}$ cooking solution affects the water content and $\mathrm{pH}$ of the paper. The higher the concentration of $\mathrm{NaOH}$ used, the more contact that occurs between the $\mathrm{NaOH}$ solution and the pulp so that the water content and $\mathrm{pH}$ of the paper decrease. According to the SNI quality standard, the permitted water content is $5 \%$, while the permitted pH level is around 6-7 (Abdel-Aal, 2013; Apriani et al. 2020; Dewi et al. 2021). 


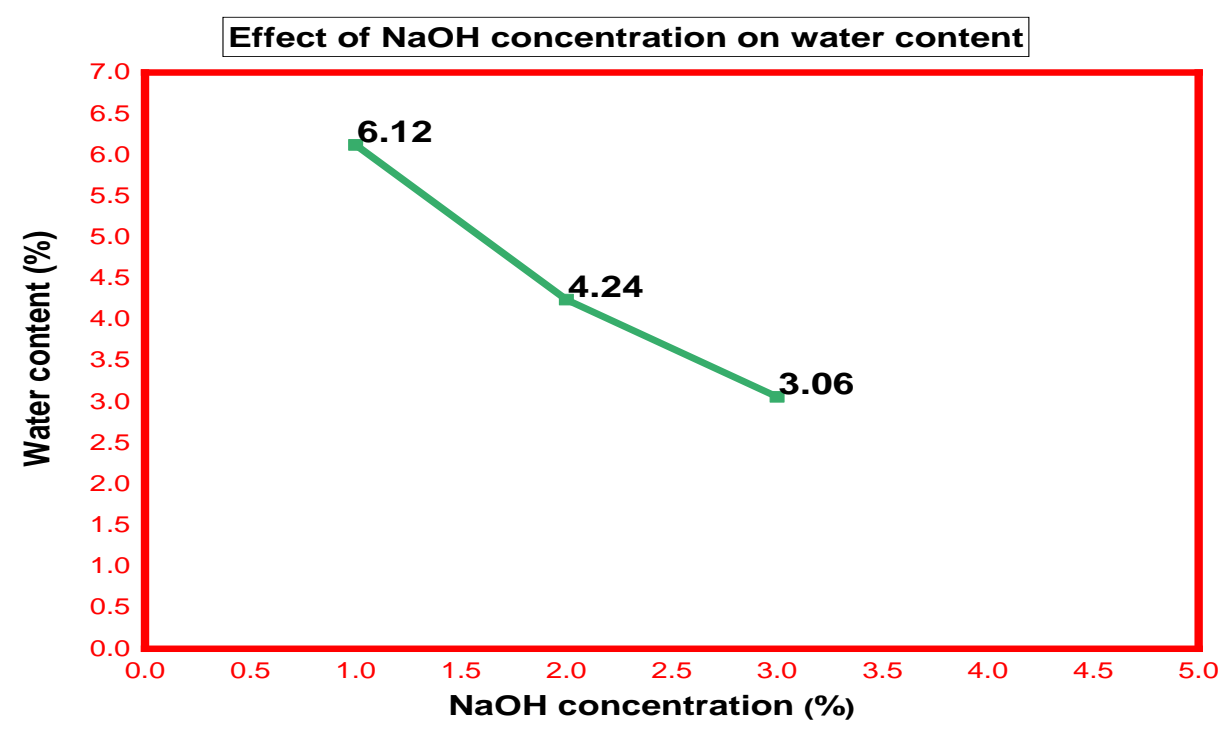

Fig 1. Water content, paper made from coconut and tofu waste

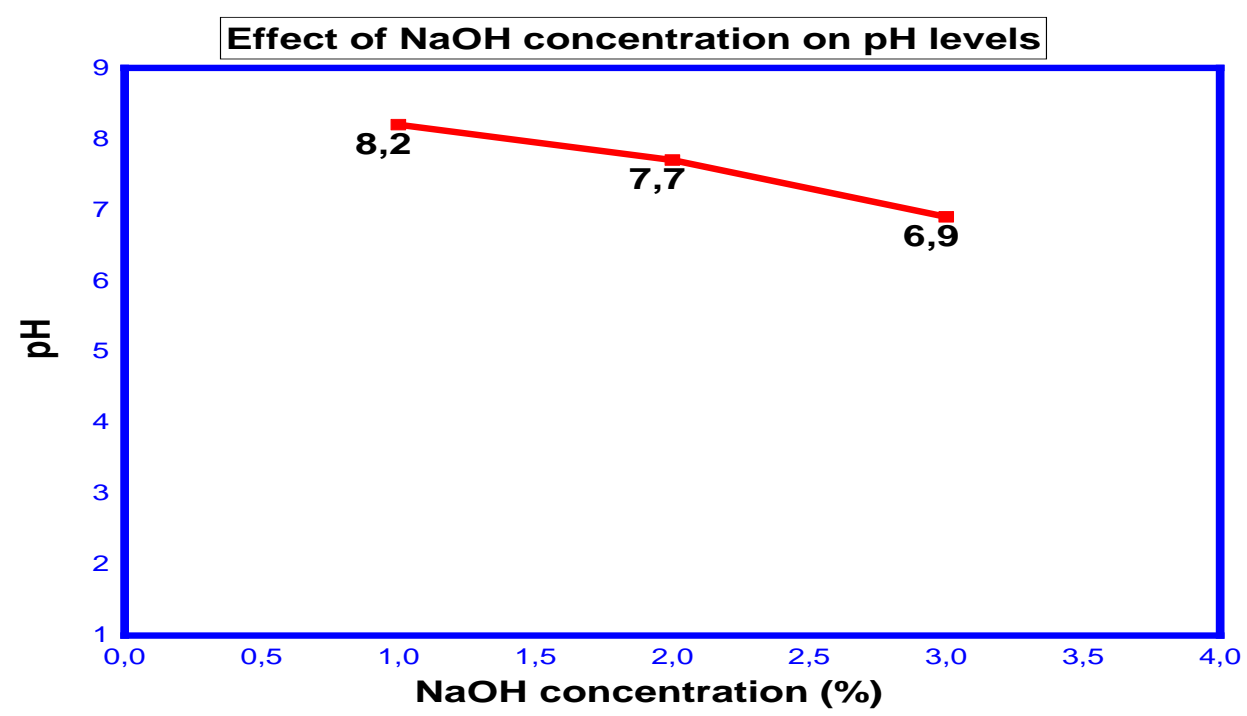

Fig 2. $\mathrm{pH}$ levels, paper made from coconut and tofu waste

\subsection{Effect of $\mathrm{NaOH}$ concentration on pulp levels}

Pulp is a material in the form of brownish fibers obtained through lignin removal process from biomass. To determine the pulp content (Fig 3). Based on Figure 3, the minimum pulp content at $1.0 \% \mathrm{NaOH}$ concentration was $45.56 \%$, while at $2.0 \% \mathrm{NaOH}$ concentration the pulp content increased to $58.65 \%$. The maximum pulp content was obtained at a $\mathrm{NaOH}$ concentration of $3.0 \%$, which was $65.75 \%$.

Pulp content increased with increasing $\mathrm{NaOH}$ concentration. The higher the concentration of $\mathrm{NaOH}$ used and the longer the hydrolysis process, the more lignin is hydrolyzed, so that the pulp content increases. According to SNI 287:2010, the pulp content that is suitable for use is 35\%-63\% (Abdel-Aal, 2013; Apriani et al. 2020; Dewi et al. 2021). 


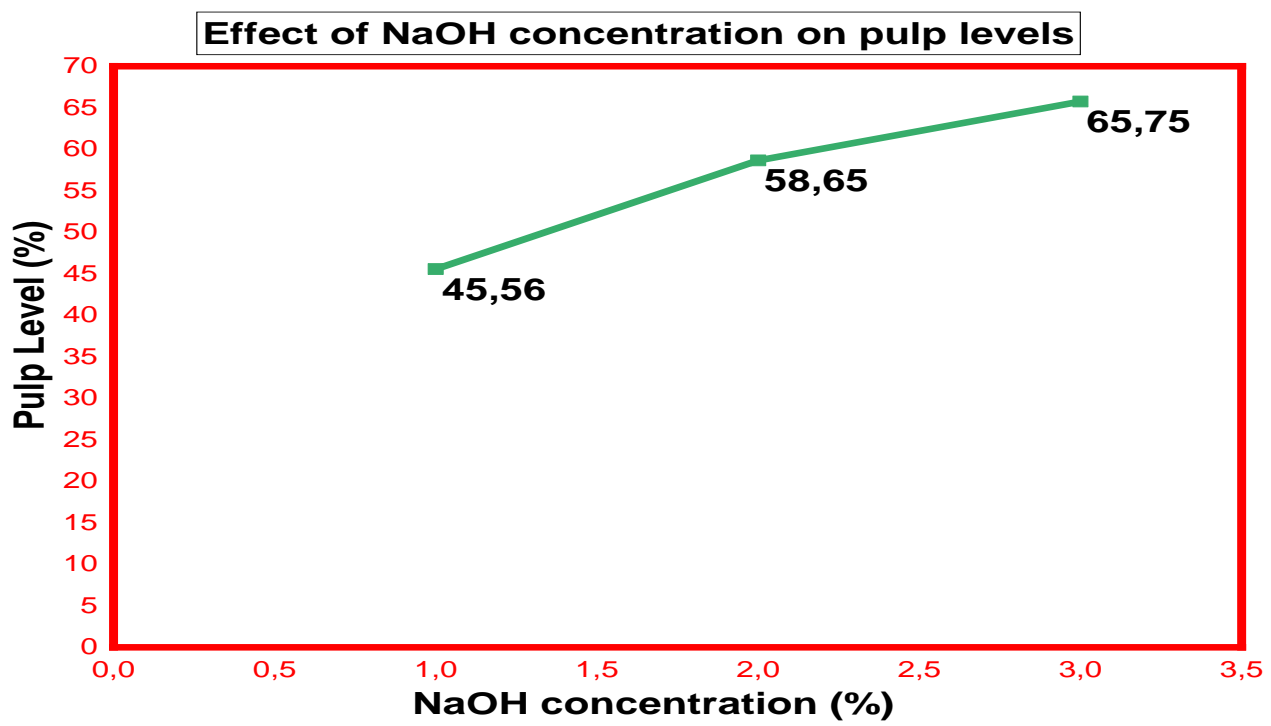

Fig 3. pulp content, paper made from coconut and tofu waste

\subsection{Effect of $\mathrm{NaOH}$ concentration on cellulose content}

Cellulose is found in most plants large in cell walls and woody parts. Cellulose has a very important role in determining the character of the fiber and its use in papermaking. In pulping, Fibers must have a high cellulose content. To determine the cellulose content (Fig 4). In Fig 4 the minimum cellulose content obtained at a concentration of $1.0 \% \mathrm{NaOH}$ is $65.25 \%$, at a $\mathrm{NaOH}$ concentration of $2.0 \%$ the cellulose content increases to $70.42 \%$, the maximum cellulose content is obtained at a $\mathrm{NaOH}$ concentration of $3.0 \%$ of $80.22 \%$.

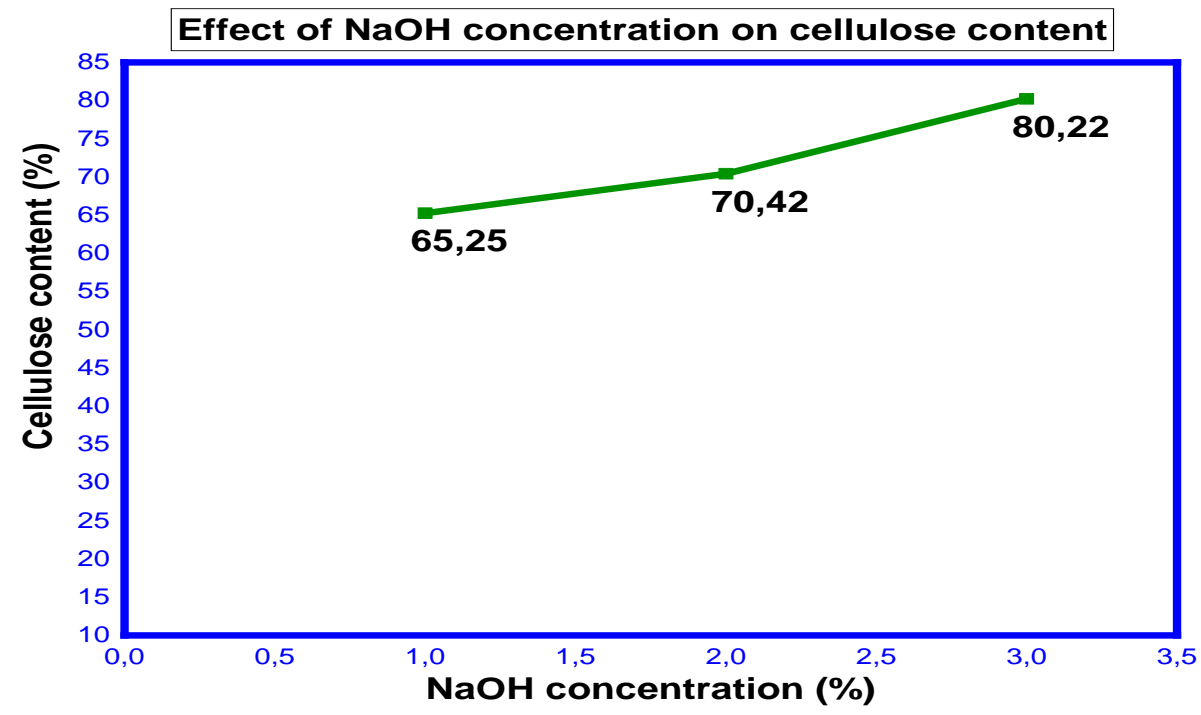

Fig 4. The cellulose content, paper made from coconut and tofu waste

Cellulose content increased with increasing concentration of $\mathrm{NaOH}$ used. The more concentration of $\mathrm{NaOH}$ used and the longer the hydrolysis process, the more lignin bound and the more pure cellulose content released (Abdel-Aal, 2013; Apriani et al. 2020; Dewi et al. 2021). 


\subsection{FT-IR analysis}

Fourier Transform Infrared Spectroscopy (FT-IR) is a technique used to obtain infrared spectra of absorbance, emission, photoconductivity or Raman Scattering of solid, liquid and gas samples. FT-IR is used to observe molecular interactions using electromagnetic radiation which is at a wavelength of $0.75-1000 \mu \mathrm{m}$ or at a wave number of $13,000^{-10} \mathrm{~cm}^{-1}$. FT-IR can also be used for qualitative analysis including functional group analysis (the presence of a 'peak' of specific functional groups) and their patterns and quantitative analysis by looking at the absorption strength of compounds at certain wavelengths. To determine the FT-IR spectrum of paper made from coconut and tofu waste (Fig 5 ).

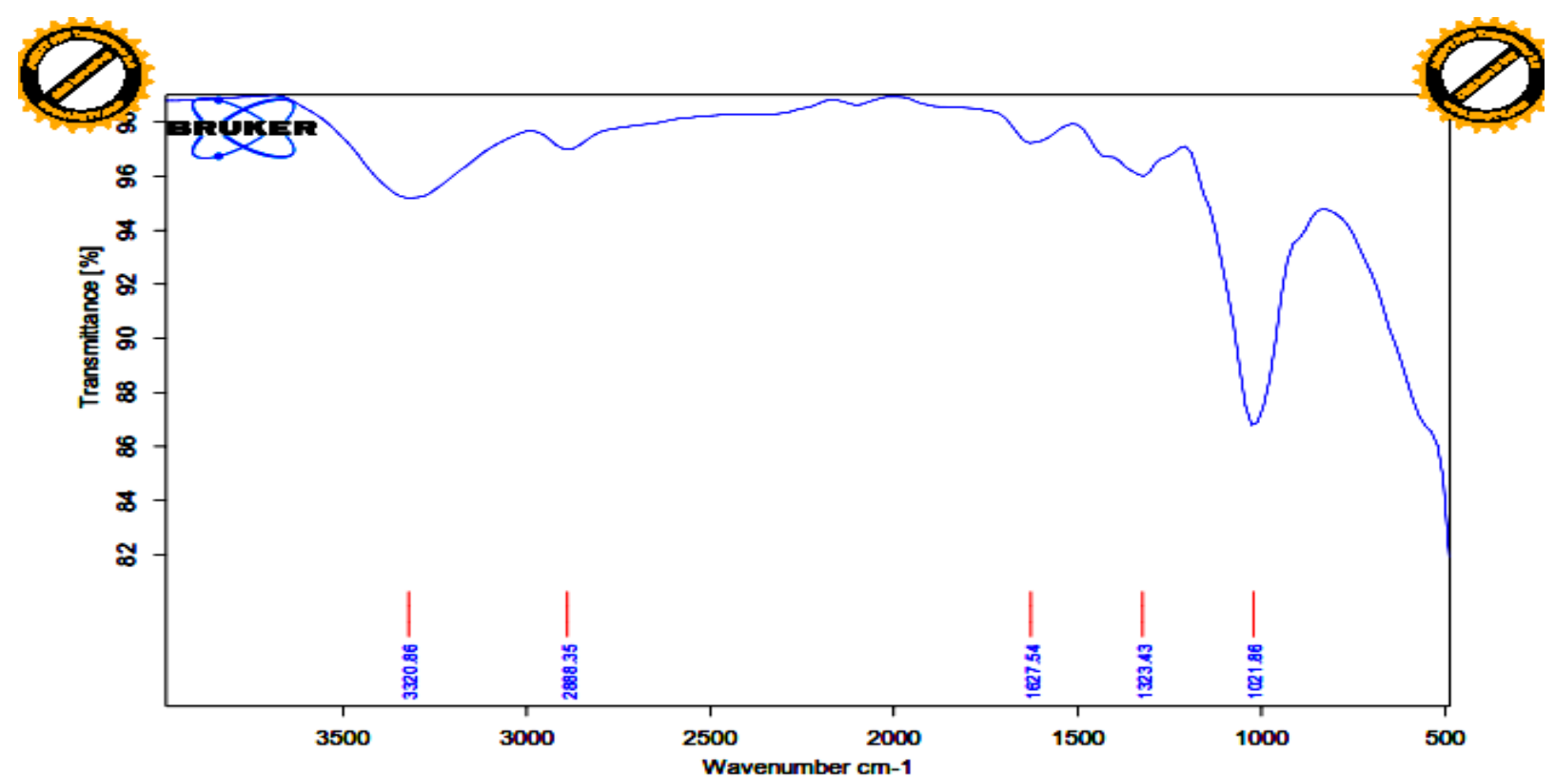

Fig 5. FT-IR spectrum of paper made from coconut and tofu waste

FT-IR spectra of paper made from coconut pulp and tofu, showing the presence of O-H hydroxyl groups, $\mathrm{C}-\mathrm{H},-\mathrm{O}-, \mathrm{C}-\mathrm{C}$, and $\mathrm{CH} 2$. At the wave number $3312.04 \mathrm{~cm}-1$ is the hydroxyl $\mathrm{OH}$ group which is a characteristic of cellulose (Aritonang et al. 2018). According to, the $\mathrm{O}-\mathrm{H}$ functional group is very strong at a wavenumber of $3312.04 \mathrm{~cm}^{-1}$. According to Aritonang et al. (2019), at a wavelength of $3700-3100 \mathrm{~cm}^{-1}$ is an $\mathrm{OH}$ group which indicates the formation of a hydrogen bond group between hydrogen atoms in one group of hydroxyl groups and another glucose monomer in the cellulose polymer chain (Aritonang et al. 2020a).

The peak wave number $2889.28 \mathrm{~cm}^{-1}$ indicates the presence of a hydrocarbon group (C$\mathrm{H}$ ) (Aritonang et al. 2020b). The peak wave number $1604.20 \mathrm{~cm}^{-1}$ indicates the presence of a carboxyl group and the peak wave number is $1326.34 \mathrm{~cm}^{-1}$. indicates the presence of $-\mathrm{CH}_{3}$ bonds, while the wave number $1022.35 \mathrm{~cm}^{-1}$ indicates the presence of ether formed, namely the C-O-C group. According to, the ether group (-O-) is shown at a wavenumber of $1045 \mathrm{~cm}^{-1}$. Based on the FT-IR spectrum with each absorption in a certain wavelength region, it shows that paper made from coconut and tofu waste are suitable to be used as raw materials for paper making because they contain cellulose. It is characterized by the presence of $\mathrm{OH}$ vibrations, - $\mathrm{C}-\mathrm{H}$ bonds, carboxyl groups (COO-), $-\mathrm{CH}_{2}$ bonds, and ether groups (-O-). 


\subsection{SEM morphological analysis}

Scanning electron microscope (SEM) is a type of microscope electrons that use the electron beam to describe the shape of surface of the analyzed sample. One of the objectives of implementing This study is to determine the structure of paper morphology from coconut pulp and tofu using SEM. To determine the morphological structure of paper made from coconut pulp and tofu (Fig 6, Fig 7 and Fig 8).

Based on Fig 6 SEM coconut waste paper with 1000 times magnification has cellulose fibers with a diameter of $15 \mu \mathrm{m}$, with low lignin content compared to tofu pulp paper, it looks like coconut pulp paper has a lighter color and smooth surface compared to Tofu dregs paper. SEM morphology of tofu dregs paper with 1000 times magnification has cellulose fibers with a diameter of $22 \mu \mathrm{m}$ with a high lignin content compared to coconut waste paper, it looks like the tofu dregs paper has a slightly opaque color and a rough surface (Fig 7).

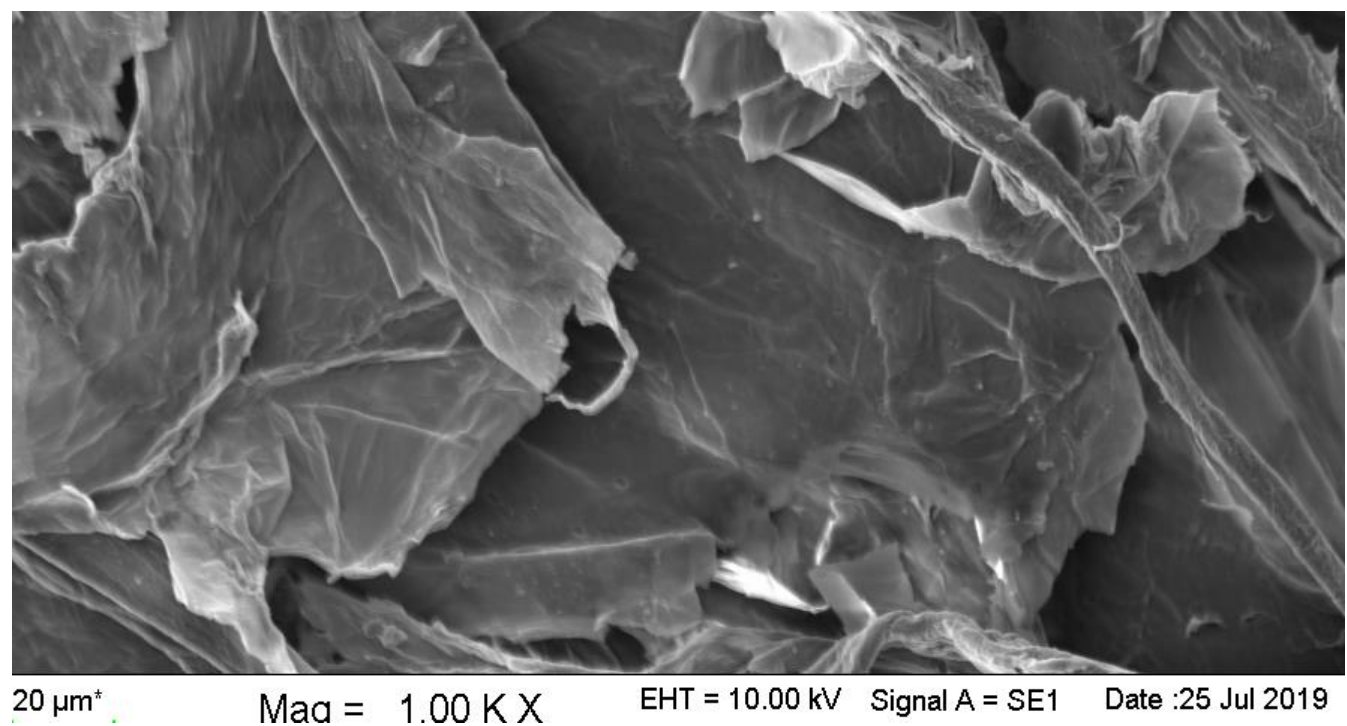

Fig 6. SEM of coconut waste paper $1000 \mathrm{KX}$ magnification

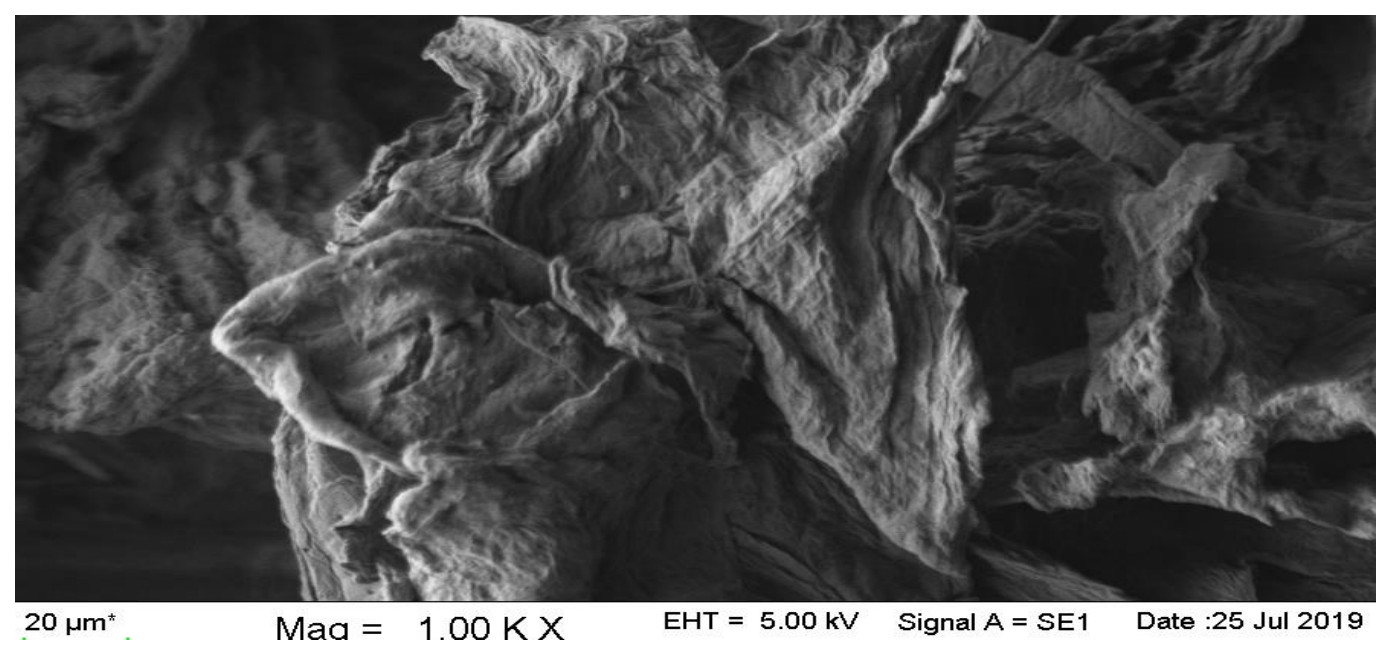

Fig 7. SEM Tofu dregs paper magnifying $1000 \mathrm{KX}$ 
SEM morphology of paper made from coconut and tofu waste combination, magnification 1000 times has a very small cellulose fiber size which is $5 \mu \mathrm{m}$ in diameter, compared with coconut waste paper and tofu dregs paper. In Fig 8 SEM the combination paper of coconut pulp and tofu, it can be seen that the morphological surface structure produced is very dense in fiber bonds, so that the mechanical properties are better, the paper produced is brighter and the surface is smoother, this proves that the smaller the diameter of the cellulose fiber, the better good mechanical properties, this is because the paper produced has a very small lignin content, the lignin content is getting smaller due to the $\mathrm{NaOH}$ solution used is able to bind the lignin content contained in the paper.

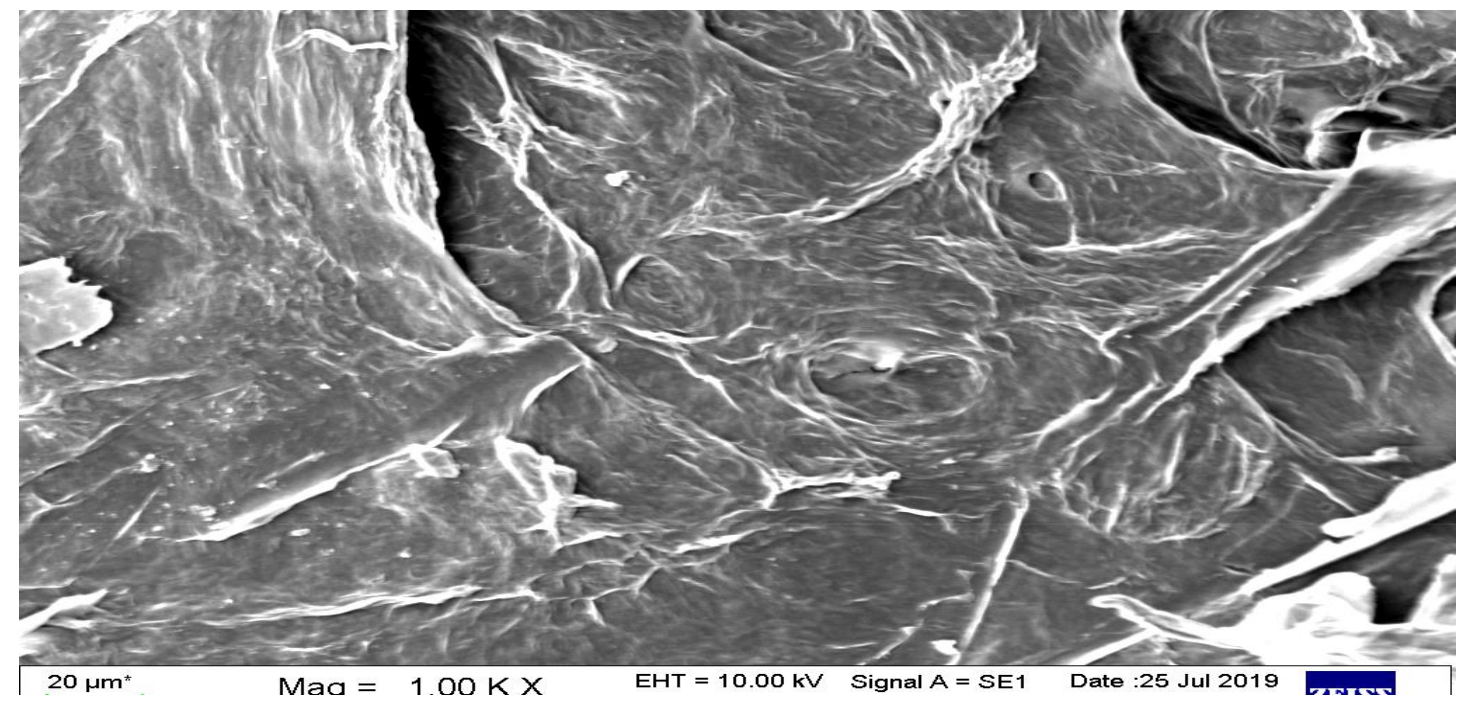

Fig 8. SEM Paper made from coconut and tofu waste $1000 \mathrm{KX}$ magnification

\subsection{XRD analysis}

X-ray diffraction (XRD) is an analytical method used to identify the crystalline phase in the material by determining the lattice structure parameters and to obtain particle size, single crystal determination. XRD characterization was carried out to analyze the phase and determine the crystal structure and degree of crystallinity of the resulting material. Crystal analysis uses an X-ray diffractometer equipped with a radiation counter to record the angle and intensity of the diffraction. A recorder records the diffraction beam plot over the 2Theta angle range.

Table 1

\begin{tabular}{l|c|c} 
Intensity of Peak characterization of coconut waste paper products \\
\hline \multirow{2}{*}{ Sample } & \multicolumn{2}{|c|}{ Paper Peak Characterization } \\
\cline { 2 - 3 } & $2 \theta$ & Intensity \\
\hline Coconut waste paper & 21.14 & 540 \\
\cline { 2 - 3 } & 17.77 & 204 \\
\cline { 2 - 3 } & 15.07 & 63 \\
\hline
\end{tabular}

Based on Fig 9 the paper from coconut dregs has a peak characteristic of crystalline structure at $2 \theta=21.14^{\circ} ; 17.77^{\circ}$ and $15.07^{\circ}$. Based on Table 1 , paper from coconut dregs has a peak characteristic of crystalline structure at $2 \theta=21.14^{\circ}$ producing an intensity of 540 , then 
the peak crystalline structure at $2 \theta$ peaks at $17.77^{\circ}$ produces an intensity of 204 and peak $2 \theta=$ $15.07^{\circ}$ produces an intensity 63 . The crystalline structure of cellulose in the cell wall can affect the properties of the resulting product, cellulose is a parameter that determines the strength of the fiber. In Fig 9 coconut pulp paper after the digester process with a $\mathrm{NaOH}$ concentration of $3.0 \%$ resulted in an increase in intensity. The highest intensity value was obtained at peak $2 \theta=21.14^{\circ}$ of 540 this was caused by the loss of lignin and hemicellulose content. In addition, the digester process with alkali can increase the amount of cellulose because treatment with alkali can restructure amorphous cellulose into crystalline cellulose.

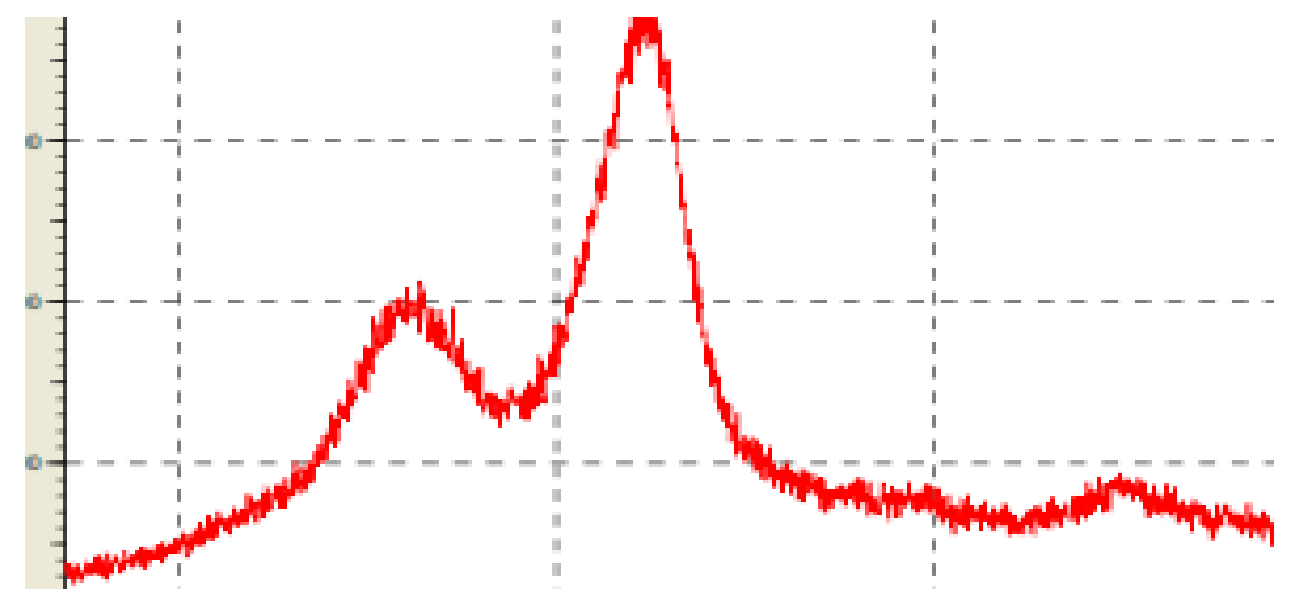

Fig 9. XRD coconut waste paper



Fig 10. XRD tofu dregs paper

Fig 10 shows that paper made from tofu dregs has peak characteristics of crystalline structure at $2 \theta=23.52^{\circ}, 17.250$, and 14.120. Based on Table 2, paper from tofu dregs has a peak characteristic of crystalline structure at $2 \theta$ producing an intensity of 158 , then at peak $2 \theta=17.25^{\circ}$ producing an intensity of 67 , and at peak $2 \theta=14.12^{\circ}$ producing an intensity of 58. In Fig 10 the Tofu dregs paper after digester process with $\mathrm{NaOH}$ concentration of $3.0 \%$ can increase peak intensity. The highest intensity value is at peak $2 \theta=23.52^{\circ}$ with an intensity value of 158. 
Table 2

Intensity of peak characterization of tofu dregs paper products

\begin{tabular}{c|c|c}
\hline \multirow{2}{*}{ Sample } & \multicolumn{2}{|c}{ Paper Peak Characterization } \\
\cline { 2 - 3 } & $2 \Theta$ & Intensity \\
\hline \multirow{2}{*}{ Tofu dregs paper } & 23.52 & 158 \\
\cline { 2 - 3 } & 17.25 & 67 \\
\cline { 2 - 3 } & 14.12 & 58 \\
\hline
\end{tabular}

Table 3

Intensity of peak characterization of paper made from coconut waste and tofu combination

\begin{tabular}{l|c|c}
\hline \multirow{2}{*}{ Sample } & \multicolumn{2}{|c}{ Paper Peak Characterization } \\
\cline { 2 - 3 } & $2 \Theta$ & Intensity \\
\hline Paper made from coconut waste and tofu & 23.52 & 525 \\
\cline { 2 - 3 } & 17.64 & 288 \\
\cline { 2 - 3 } & 15.27 & 87 \\
\hline
\end{tabular}

Based on Fig 11 the combination of paper made from coconut waste and tofu has a characteristic peak of crystalline structure at $2 \theta=23.52^{\circ} ; 17.64^{\circ}$ and $15.27^{\circ}$. Based on Table 3 , the combination of coconut pulp and tofu pulp has a characteristic peak of crystalline structure at $2 \theta=23.52^{\circ}$ producing an intensity of 525 , then peak $2 \theta=17.64^{\circ}$ produces an intensity of 288 , and peak $2 \theta=15.27^{\circ}$ produces intensity 87 . The crystalline structure of cellulose in the cell wall can affect the properties of the resulting product, cellulose is a parameter that determines the strength of the fiber. In Fig 11 the paper combination of coconut pulp and tofu pulp after the digester process with $\mathrm{NaOH}$ concentration of $3.0 \%$ resulted in an increase in intensity. The highest intensity value was obtained at peak $2 \theta=$ $23.52^{\circ}$ of 525 this was caused by the loss of lignin and hemicellulose content. In addition, the digester process with alkali can increase the amount of cellulose because treatment with alkali can restructure amorphous cellulose into crystalline cellulose (Lee et al. 2016; George et al. 2019).

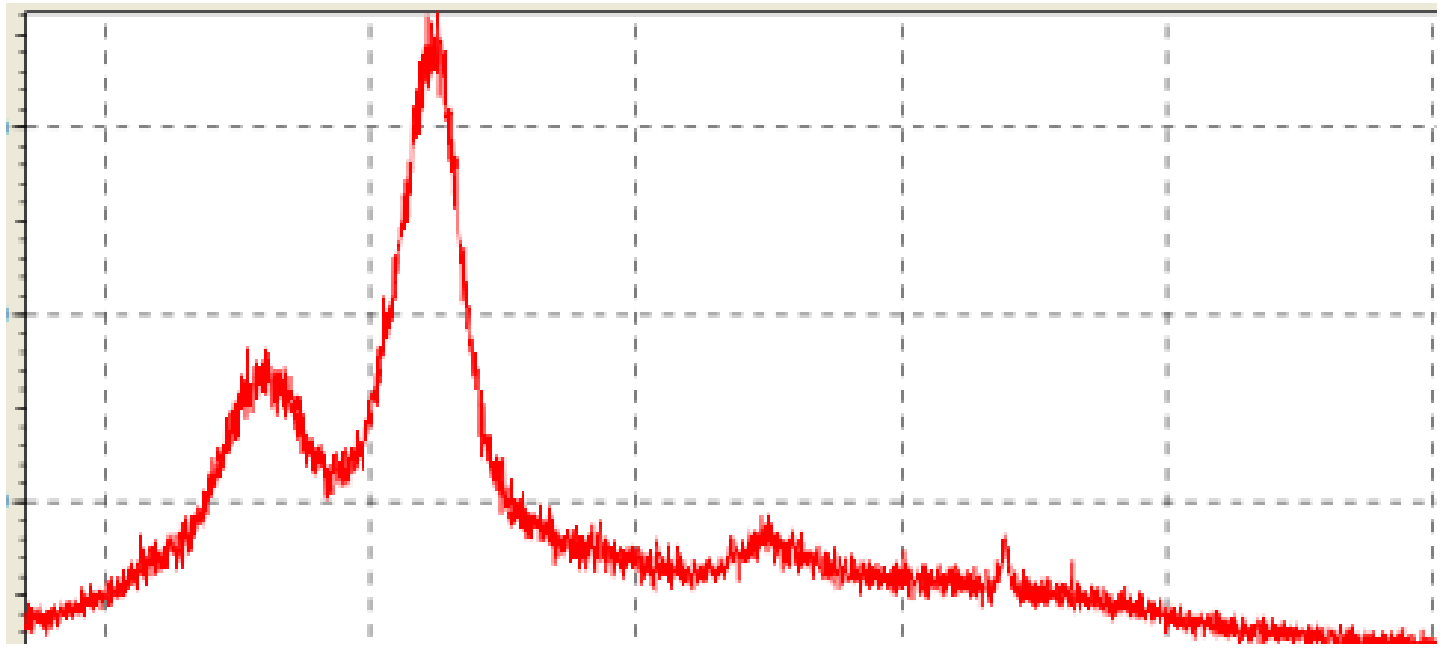

Fig 11. XRD paper made from coconut waste and tofu 


\subsection{Gramature test}

Paper gramature is defined as the mass of a sheet of paper divided by its area $\left(\mathrm{m}^{2}\right)$ expressed in $\mathrm{g} / \mathrm{m}^{2}$. The grammage is determined based on SNI ISO 536:1995, namely the determination of the value of crack resistance refers to the SNI ISO 2758-2010 method. The tensile index value refers to the SNI ISO 1924-22010 method. The tear index value refers to the SNI ISO 0436-2009 method. Based on SNI ISO 1924-2-2010 the minimum allowable tensile index value is $\leq 30 \mathrm{Nm} / \mathrm{g}$.

\section{Table 4}

Grammage Test of Coconut and Tofu pulp paper

\begin{tabular}{c|c|c|c}
\hline $\begin{array}{c}\mathrm{NaOH} \\
\text { concentration }\end{array}$ & $\begin{array}{c}\text { Tensile index } \\
(\mathrm{Nm} / \mathrm{kg})\end{array}$ & $\begin{array}{c}\text { Crack resistance } \\
(\mathrm{Kpa})\end{array}$ & $\begin{array}{c}\text { Torn index } \\
\mathrm{mNm}^{2} / \mathrm{g}\end{array}$ \\
\hline 1.0 & 18.7 & 20.4 & 24.7 \\
\hline 2.0 & 25.6 & 28.6 & 35.2 \\
\hline 3.0 & 30.2 & 45.8 & 57.8 \\
\hline
\end{tabular}

The grammage test for the tensile index value of coconut pulp and tofu paper at a $\mathrm{NaOH}$ concentration of $3.0 \%$ obtained a value of $30.2 \mathrm{Nm} / \mathrm{kg}$, the value of crack resistance was 45.8 $\mathrm{Kpa}$, while the tear index value was $57.8 \mathrm{mNm}^{2} / \mathrm{g}$ (Table 4). The results of the research that has been done, show that it has met the requirements of SNI ISO 1924-2-2010. From the results of this study, it can be concluded that the concentration of $\mathrm{NaOH}$ and starch binder cassava peel effect the tensile index, crack resistance, and tear index produced. If the concentration of $\mathrm{NaOH}$ and cassava peel starch binder increases, the tensile index, crack resistance and tear index of the resulting pulp will increase and vice versa if the concentration of $\mathrm{NaOH}$ and cassava peel starch binder decreases, the tensile index, crack resistance, and tear index of the resulting pulp will also decrease.

\section{Conclusion}

The optimum composition of the paper-making process from coconut pulp and tofu waste using the alkalization separation technique is the $\mathrm{NaOH}$ concentration used is $3.0 \%$, the cooking temperature is $100{ }^{\circ} \mathrm{C}$ within 90 minutes. Paper made from coconut pulp and tofu has met the requirements set by SNI 14-0444-1989, namely 3.2\% water content; $\mathrm{pH}$ 6.9, pulp content $65.75 \%$; cellulose content $80.22 \%$; lignin content $18.27 \%$. The results of the FT-IR spectrum analysis of coconut pulp and tofu pulp are suitable to be used as raw materials for making paper because they contain cellulose fiber. This is indicated by the appearance of the $\mathrm{O}-\mathrm{H}$ hydroxyl group which is observed at a wavenumber of $3312 \mathrm{~cm}^{-1}$. The results of SEM analysis of the surface morphology of the coconut pulp and tofu combination paper show that the surface structure is the tighter the fiber bonds, the smaller its fiber diameter, the better the mechanical properties.

\section{Acknowledgment}

Researchers would like to thank the Universitas Sari Mutiara Indonesia and Medan State University for providing facilities for the implementation of this research. 


\section{References}

Abdel-Aal, M. A. (2013). Effect of cooking time, active alkali concentration and refining process on the pulping and papermaking properties of buttonwood residues (Conocarpus erectus L.). World Applied Sciences Journal, 27(1), 01-09.

Abd El-Sayed, E. S., El-Sakhawy, M., \& El-Sakhawy, M. A.-M. (2020). Non-wood fibers as raw material for pulp and paper industry. Nordic Pulp \& Paper Research Journal, 35(2), 215-230. DOI:10.1515/npprj-2019-0064

Amit, K., Nakachew, M., Yilkal, B., \& Mukesh, Y. (2018). A review of factors affecting enzymatic hydrolysis of pretreated lignocellulosic biomass. Res J Chem Environ, 22(7), 62-67.

Apriani, R., Manik, N. N., Mahardhika, E. H., \& Inayatullah, M. J. (2020). Study on the utilization of palm fruit waste as a pulp raw material organosolv method with hydrothermal pretreatment. Journal of Physics: Conference Series, 1456, 012003. DOI:10.1088/1742-6596/1456/1/012003

Aprianti, T. (2019). Utilization of sugarcane bagasse and banana midrib mixture as raw materials for paper making using acetosolve method. IOP Conference Series: Materials Science and Engineering, 620, 012020. DOI:10.1088/1757-899x/620/1/012020

Aritonang, B., Tamrin, T., Wirjosentono, B., \& Eddiyanto, E. (2018). Functionalization of cyclic natural rubber (CNR) with oleic acid and divinylbenzene as compatibilizer in variation of dicumylperoxide. AIP Conference Proceedings, 2049, 020060. DOI:10.1063/1.5082465

Aritonang, B., Tamrin, T., Wirjosentono, B., \& Eddiyanto, E. (2019). Grafting of oleic acid on cyclic natural rubber resiprene-35 using dicumyl peroxide initiator and divinylbenzene compatibilizers for paint binder in polyamide thermoplastics. Oriental Journal of Chemistry, 35(1), 173-179. DOI:10.13005/ojc/350119

Aritonang, B., Tamrin, Wirjosentono, B., \& Eddiyanto. (2020a). Grafting copolymer cylic natural rubber with oleic acid using dicumyl peroxide as initiator. AIP Conference Proceeding, 2267, 020013. DOI:10.1063/5.0025153

Aritonang, B., Tamrin, Wirjosentono, B., \& Eddiyanto. (2020b). Effect of graft copolymerization of oleic acid on to cyclic natural rubber in polyamide. Case Studies in Thermal Engineering, 21, 100690. DOI:10.1016/j.csite.2020.100690

Bialkowski, W. L. (2018). Control of the pulp and paper making process. Control System Applications, 43-66. DOI:10.1201/9781315214061-4

Barbash, V. A., \& Yashchenko, O. V. (2020). Preparation and application of nanocellulose from nonwood plants to improve the quality of paper and cardboard. Applied Nanoscience, 10(8), 27052716. DOI:10.1007/s13204-019-01242-8

Dewi, I. A., Ihwah, A., Setyawan, H. Y., Kurniasari, A. A. N., \& Ulfah, A. (2021). Optimization of NaOH concentration and cooking time in delignification of mature coconut (Cocus nucifera L.) coir. IOP Conference Series: Earth and Environmental Science, 733, 012034. DOI:10.1088/17551315/733/1/012034

George, B., Lal, N., \& Suchithra, T. V. (2019). Nanocellulose as polymer composite reinforcement material. Nanotechnology in the Life Sciences, 409-427. DOI:10.1007/978-3-030-16379-2_14

Khan, M. Z. H., Sarkar, M. A. R., Al Imam, F. I., Khan, M. Z. H., \& Malinen, R. O. (2014). Paper making from banana pseudo-stem: Characterization and comparison. Journal of Natural Fibers, 11(3), 199211. DOI:10.1080/15440478.2013.874962

Lee, K.-Y., \& Bismarck, A. (2016). Bacterial nanocellulose as reinforcement for polymer matrices. Bacterial Nanocellulose, 109-122. DOI:10.1016/b978-0-444-63458-0.00006-8

Li, R., Buongiorno, J., Turner, J. A., Zhu, S., \& Prestemon, J. (2008). Long-term effects of eliminating illegal logging on the world forest industries, trade, and inventory. Forest Policy and Economics, 10(7-8), 480-490. DOI:10.1016/j.forpol.2008.04.003 
Mauro, C. S. I., \& Garcia, S. (2019). Coconut milk beverage fermented by Lactobacillus reuteri: optimization process and stability during refrigerated storage. Journal of Food Science and Technology, 56(2), 854-864. doi:10.1007/s13197-018-3545-8

Widayat, W., Plilia, J., \& Wibisono, J. (2019). Liquid waste processing of tofu industry for biomass production as raw material biodiesel production. IOP Conference Series: Earth and Environmental Science, 248, 012064. DOI:10.1088/1755-1315/248/1/012064 